\title{
Effects of Castration on the Smoltification of Precocious Male Masu Salmon Oncorhynchus masou
}

\author{
Katsumi AIDA, ${ }^{* 1}$ Teiichi KATo, ${ }^{* 2}$ and Masahiko AWAJI ${ }^{* 1}$ \\ (Accepted July 21, 1983)
}

\begin{abstract}
Underyearlings of precocious male masu salmon were castrated in August and then were reared until next April under natural conditions to study the effect of castration on the induction of smoltification.

Forty seven out of 196 castrated fish which survived until April were completely castrated. Of these fish, larger ones became smolt, whereas smaller ones did not become smolt. Other 149 castrated fish had a small piece of remaining testis and smoltification did not occurr. All the sham operated fish had a small testis and were parr. Plasma androgen levels were low (about $1 \mathrm{ng} / \mathrm{ml}$ ) in both partially castrated and sham operated fish in April.

These results indicate that precocious maturation inhibits the parr to smolt transformation and plasma androgen concentration of about $1 \mathrm{ng} / \mathrm{ml}$ is probably high enough to prevent the transformation. Growth rate is also an important factor in inducing smoltification as well as gonadal immaturity.
\end{abstract}

Mature masu salmon Oncorhynchus masou migrate into the river in northern Japan for spawning in early summer and spawn in autumn., ${ }^{1,2}$ After hatching, juvenile fish stay in the river for about one year and half and then migrate into the sea after the parr to smolt transformation in spring. ${ }^{g-\eta}$ ) But the underyearling male masu salmon which show rapid growth after hatching, precociously mature in the first autumn. Precocious males never become smolt in the next spring and keep staying in the fresh water, while underyearling females, which are usually immature in the first autumn, and inmature males become smolt and migrate into the sea in the following spring. ${ }^{3-7)}$ These phenomena suggest that the precocious maturation of the testis probably inhibits the parr to smolt transformation in these fish. But until now little is known of the physiological relationship between smoltification and gonadal maturation in salmonid fishes. In this paper, we attempted to castrate precocious male masu salmon and further studied the effect of castrstion on the induction of the parr to smolt transformation.

\section{Material and Methods}

Fish

Precocious male masu salmon were selected as experimental material on August 14, 1981 from the underyearling stocks which were reared from eggs at the Nikko Branch of National Research Institute of Aquaculture, Nikko, Tochigi Prefecture. These eggs were obtained from mature masu salmon which had migrated into the river Shiribetsu, Hokkaido in the autumn of 1980, and then transported to the Institute mentioned above. Gonadosomatic index of the precocious males used in this experiment was $7.3 \pm 1.3 \%$ (mean \pm S.E. $N=11$ ) and the testis showed active spermatogenesis. Average body length was $9.9 \mathrm{~cm}$ at the commencement of the experiment as shown in Table 1.

\section{Castration}

Fish were anesthetized with ethyl p-aminobenzoate at the concentration of $100 \mathrm{ppm}$. Initially an incision approximately $1.5 \mathrm{~cm}$ in length was performed in the midline between pectoral and ventral fins, and then testis was resected with a pair of forceps. After the removal of the testis, the incision was closed with a tripple knots suture. Three hundred and sixteen precocious males were castrated and 107 precocious males were sham operated on August 14, 1981.

\section{Experiment}

Castrated fish were marked by cutting the

*1 Laboratory of Fish Physiology, Faculty of Agriculture, The University of Tokyo, Bunkyo, Tokyo 113, Japan (会田勝美・淡路雅彦：東京大学農学部).

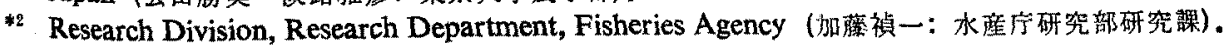


Table 1. Survival, growth and smoltification of precocious male masu salmon after castration and sham operation

\begin{tabular}{|c|c|c|c|c|c|c|}
\hline \multirow[b]{2}{*}{ Date } & \multicolumn{3}{|c|}{ Castrated } & \multicolumn{3}{|c|}{ Sham Operated } \\
\hline & $\begin{array}{l}\text { No. of } \\
\text { Survival }\end{array}$ & $\begin{array}{l}\text { Average } \\
\text { BL }(\mathrm{cm})\end{array}$ & $\begin{array}{l}\text { No. of } \\
\text { Smolt* }\end{array}$ & $\begin{array}{l}\text { No. of } \\
\text { Survival }\end{array}$ & $\begin{array}{l}\text { Average } \\
\text { BL (cm) }\end{array}$ & $\begin{array}{l}\text { No. of } \\
\text { Smolt* }\end{array}$ \\
\hline Aug. 14,1981 & 316 & 9.9 & 0 & 107 & 9.9 & 0 \\
\hline Dec. 23,1981 & 230 & 11.4 & 0 & 49 & 11.1 & 0 \\
\hline Mar. 2, 1982 & 208 & 13.1 & 0 & 40 & 12.4 & 0 \\
\hline Apr. 23,1982 & 196 & 14.8 & 35 & 36 & 14.0 & 0 \\
\hline
\end{tabular}

adipose fin and reared with sham operated fish in a round indoor tank $1.5 \mathrm{~m}$ in diameter and $1000 \mathrm{l}$ in volume under natural photoperiod from August 14, 1981 to April 23, 1982 at the Nikko Branch of National Research Institute of Aquaculture. The tank was supplied with fresh spring water of which temperature was almost constant $\left(10^{\circ} \mathrm{C}\right)$ throughout the year. Fish were fed with commercial trout food. In August, December, March and April, measurements were made on body length and body weight and degree of smoltification was determined by the appearance of the fish. As to the criteria for masu salmon smolt, strong silvery body surface which made parr marks almost invisible, occurrence of black margin in dorsal and caudal fins and slimness of the body were adopted in this experiment.

At the end of the experiment, blood was taken from both groups. Plasma was stored at $-20^{\circ} \mathrm{C}$ until analysis. Sea water challenge test was carried out to test the sea water adaptability using artificial sea water $(874 \mathrm{mOsm} / 1$; Jamarin Lab.) at $10^{\circ} \mathrm{C}$ for 24 hours. After the challenge test, blood was taken from the fish which could survive for 24 hours.

\section{Analysis}

The concentrations of plasma $\mathrm{Na}, \mathrm{Ca}$ and $\mathrm{Mg}$ were measured by atomic absorption. Plasma thyroxine (T4) level was measured by radioimmunoassay technique reported by DickноFF et al. with the following modification. Antibody was obtained from Wien Laboratories, Inc. (Lot $1628 \mathrm{~A}$ ) and high specific activity (>1200 $\mathrm{mCi} / \mathrm{mg})$ ${ }^{126}$ I-labeled T4 was purchased from Amersham International Ltd. For the assay, $20 \mu \mathrm{l}$ of plasma or T4-standards were added in duplicate to the assay tubes. To assay tubes containing standard or plasma, $60 \mu \mathrm{l}$ of radioactive T4 (about $10^{4} \mathrm{cpm}$ ) solution, $60 \mu l$ of ANS (8-anilino-1-naphthalenesulfonic acid, sodium salt $0.036 \mathrm{mg}$ ) and bovine $\gamma$-globulin $(0.15 \mathrm{mg})$ solution : and $60 \mu \mathrm{l}$ of anti- serum were added. To prepare these solutions, $0.11 \mathrm{M}$ barbital buffer ( $\mathrm{pH} \mathrm{8.6)}$ was used. Antiserum was previously diluted to a concentration which could result in $40-50 \%$ labeled $\mathrm{T} 4$ bound with no added unlabeled $T 4$. Tubes were incubated for overnight at $4^{\circ} \mathrm{C}$. Antibody was then precipitated by addition of $0.5 \mathrm{~m} l$ cold $20 \%$ $(w / v)$ polyethylene glycol. The precipitate was then centrifuged at $3200 \mathrm{rpm}$ for $20 \mathrm{~min}$ at $4^{\circ} \mathrm{C}$. The supernatant was then aspirated, and the precipitate was counted in a gamma well counter for $5 \mathrm{~min} /$ tube. Intraassay and interassay coefficients of variation for RIA were $5.4 \%(\mathrm{~N}=5)$ and $8.2 \%(\mathrm{~N}=5)$, respectively at about $50 \%$ binding. Plasma androgen level was also measured by radioimmunoassay. Rabbit anti-testoterone-11 $\alpha$-hemiscuccinate-BSA was obtained from Teikokuzoki Pharm. Company (lot No. GD-31) and $\left(1,2,6,7{ }^{8} \mathrm{H}\right)$ testosterone (Amersham International Ltd.) was used as labeled hormone. Extract $(\times 2)$ from $50 \mu \mathrm{l}$ of plasma with $1.5 \mathrm{ml}$ of ether was dried under nitrogen gas and then dissolved with $0.2 \mathrm{ml}$ of $0.1 \%$ Gel-PBS. To the assay tubes containing $0.2 \mathrm{~m} l$ of standard or plasma extract, $100 \mu l$ of Gel-PBS containing radioactive testosterone $\left(10^{4} \mathrm{cpm}\right)$ and $200 \mu l$ of EDTA-PBS containing adequate amount of antiserum which would result in about $\mathbf{3 0} \%$ labeled testosterone bound, were added. Incubation was undertaken for overnight at $4^{\circ} \mathrm{C}$. After incubation, free and bound radioactive testosterone was separated with $0.25 \mathrm{~m} l$ of dextran-coated charcoal. The supernatant was counted with liquid scintilation spectrometer. Intraassay coefficient of variation for RIA was $8.7 \%(\mathrm{~N}=5)$ at about $50 \%$ binding. Since this antibody equally cross-reacts with 11 ketotestosterone and testosterone and both steroids are main constituents of salmonid androgen, this system measures total androgen in the plasma. For histological observation, testis was fixed in $10 \%$ neutral formalin and embedded in paraffin. Sections were stained with hematoxylin and eosin. 


\section{Results}

Growth and survival of both castrated and sham operated groups are summarized in Table 1. All the fish were classified into smolt, presmolt, parr and dark parr by the appearance in December, March and April. No smolt was seen on December 23 and March 2 in either group. On April 23, 35 out of 196 castrated fish were classified as smolt and presmolt from the appearance, whereas neither smolt nor presmolt was present in sham operated group.

At the end of the experiment, all the fish were dissected to check the success of castration and gonadal maturation. In the castrated group, 47 out of 196 fish were found completely castrated, whereas 149 fish possessed a small remaining piece of testis. Eighteen, 17 and 12 out of 47 completely castrated fish were determined as smolt, presmolt and parr, respectively as shown in Table 2. All the 149 fish with partial castration were classified as parr. Sham operated fish were also classified into parr. Typical apparance of completely castrated smolt, partially castrated parr and sham operated parr were shown in Plate I-1, 2 and 3. The distributions of body length are depicted as histogram in Fig. 1. Average body lengths of smolt, presmolt and parr in the completely castrated group were 15.3, 13.6, 12.8 $\mathrm{cm}$, respectively. Average body lengths of the partially castrated and sham operated fish were 15.0 and $14.0 \mathrm{~cm}$, respectively.

Average gonadosomatic index of the partially castrated fish was $0.88 \%$ and active spermatogenesis was recognized in more than half of the fish. Sham operated fish showed inactive spermatogenesis and average gonadosomatic index was $0.41 \%$. Plasma androgen was undetected in the completely castrated fish. The level were $1.14 \mathrm{ng} / \mathrm{m} l$ and $0.94 \mathrm{ng} / \mathrm{m} l$, respectively in partially castrated and sham operated fish.

Percent changes in body weight and the con- centrations of plasma $\mathrm{Na}, \mathrm{Ca}$ and $\mathrm{Mg}$ after 24 hours in sea water are summarized in Table 3 . In smolt, decrease in body weight and increase in plasma $\mathrm{Na}$ and $\mathrm{Mg}$ were smaller than those in presmolt and parr. Presmolt showed intermediate values. These was no difference in these values between partially castrated and sham

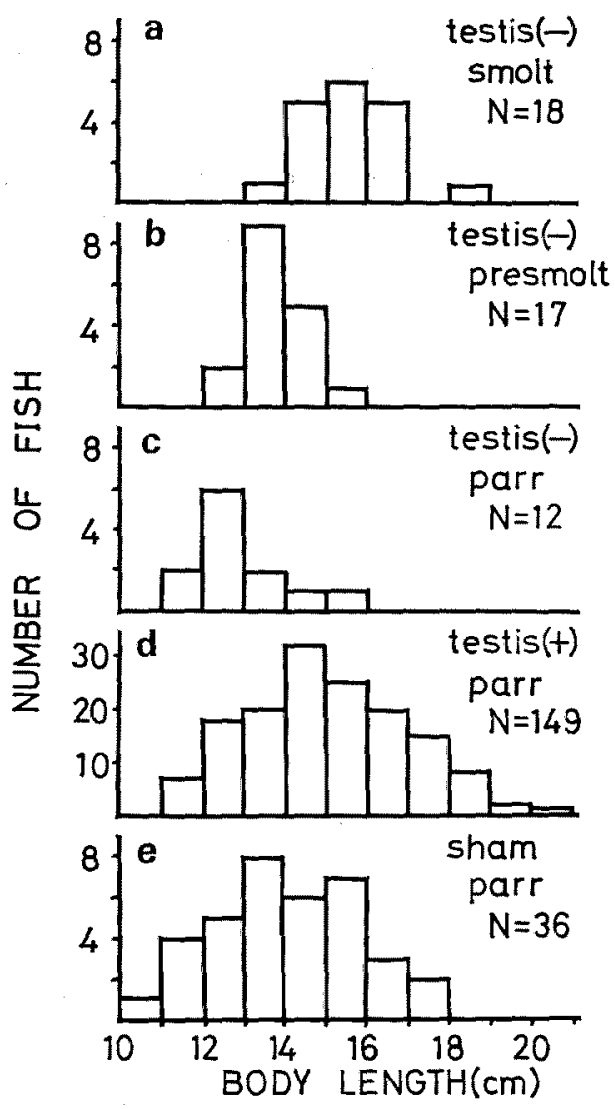

Fig. 1. Histograms showing the distributions of body length of completely castrated smolts (a), completely castrated presmolts (b), completely castrated parr (c), partially castrated parr (d) and sham operated parr (e).

Table 2. Numbers of smolts, presmolts and parr in castrated and sham operated precocious masu salmon, GSI and androgen contents in April

\begin{tabular}{|c|c|c|c|c|c|}
\hline \multicolumn{2}{|c|}{$\begin{array}{l}\text { Experimental Group \& } \\
\text { Degree of Castration }\end{array}$} & \multirow{2}{*}{ Appearance } & \multirow{2}{*}{$\begin{array}{c}\text { No. of } \\
\text { Fish } \\
18\end{array}$} & \multirow{2}{*}{$\frac{G S I(\%)}{0}$} & \multirow{2}{*}{$\frac{\text { Androgen }(\mathrm{ng} / \mathrm{ml})}{<0.12(8)}$} \\
\hline & $\therefore$ & & & & \\
\hline \multirow{3}{*}{ Castrated } & Completely & Presmolt & 17 & 0 & $<0.12(7)$ \\
\hline & & Parr & 12 & 0 & - \\
\hline & Partially & Parr . & 149 & $0.88 \pm 0.22(30)$ & $1.14 \pm 0.14(8)$ \\
\hline \multicolumn{2}{|c|}{ Sham Operated } & Parr & 36 & $0.41 \pm 0.25(27)$ & $0.94 \pm 0.20(8)$ \\
\hline
\end{tabular}

GSI and androgen content are shown as mean \pm S.E.

Number in parentheses indicates the number of fish examined. 
Table 3. Percent changes in body weight and plasma $\mathrm{Na}, \mathrm{Ca}$ and $\mathrm{Mg}$ contents after sea water challenge test in April

\begin{tabular}{|c|c|c|c|c|c|c|}
\hline $\begin{array}{l}\text { Degree of } \\
\text { Castration }\end{array}$ & Appearance $I$ & & $\mathrm{BW}(\%)$ & $\mathrm{Na}(\mathrm{mM})$ & $\mathrm{Ca}(\mathrm{mM})$ & $\mathrm{Mg}(\mathrm{mM})$ \\
\hline $\begin{array}{l}\text { Completely } \\
\text { Castrated }\end{array}$ & $\left\{\begin{array}{l}\text { Smolt } \\
\end{array}\right.$ & 9 & $-8.25 \pm 1.56777$ & $157.0 \pm 6.777$ & $4.54 \pm 0.1477$ & $1.90 \pm 0.24 \longrightarrow 7$ \\
\hline & Presmolt & 7 & $-12.42 \pm 0.76^{\rfloor}$ & $164.5 \pm 7.6$ & $4.92 \pm 0.13 \square * 1$ & $2.32 \pm 0.13$ \\
\hline $\begin{array}{l}\text { Partially } \\
\text { Castrated }\end{array}$ & Parr & $7^{* 3}$ & $-13.40 \pm 0.69-$ & $197.7 \pm 14.5^{* 2}$ & $4.19 \pm 0.08 \stackrel{* 2}{-}$ & $3.48 \pm 0.48^{* 1}$ \\
\hline $\begin{array}{l}\text { Sham } \\
\text { Operated }\end{array}$ & Part & 9 & $-13.26 \pm 0.69 \ldots$ & $185.9 \pm 8.4 \square$ & $4.67 \pm 0.08]^{* 2}$ & $3.27 \pm 0.38 \longrightarrow$ \\
\hline
\end{tabular}

$* 1 \mathrm{P}<0.05, * 2 \quad \mathrm{P}<0.01$, new multiple-range test of Duncan.

*3 Two fish died within 24 hours.

Data are shown as mean \pm S.E.

Table 4. Plasma Thyroxine levels of masu salmon in fresh water and after sea water challenge test

\begin{tabular}{|c|c|c|c|c|c|}
\hline \multirow{2}{*}{ Degree of Castration } & \multirow{2}{*}{ Appearance } & \multicolumn{4}{|c|}{ Thyroxine $(\mathrm{ng} / \mathrm{m} l)$} \\
\hline & & $\mathbf{N}$ & FW & $\mathrm{N}$ & SW $(24 h)$ \\
\hline \multirow{2}{*}{ Completely Castrated } & Smolt & 8 & $18.0 \pm 4.0$ & 9 & $7.4 \pm 2.5$ \\
\hline & lPresmolt & 7 & $23.9 \pm 6.1-$ & 7 & $7.4 \pm 1.4$ \\
\hline Partially Castrated & Parr & 8 & $18.6 \pm 2.6 * 1$ & 7 & $4.3 \pm 1.3$ \\
\hline Sham Operated & Parr & 8 & $10.4 \pm 2.0-$ & 9 & $5.2 \pm 0.7$ \\
\hline
\end{tabular}

*1 $P<0.05$, new multiple-range test of Duncan.

Data are shown as mean \pm S.E.

operated parr. Two fish died within 24 hours in the partially castrated group, whereas all the fish in other groups survived until the end of the sea water challenge test. Partially castrated parr showed the lowest level of $\mathrm{Ca}$ in all groups.

Plasma thyroxine levels are shown in Table 4. The level was highest in presmolt. In completely castrated smolts and partially castrated parr the thyroxine level was almost the same. The level was lowest in sham operated parr. After 24 hours in sea water, plasma thyroxine level rapidly decreased in all groups.

\section{Discussion}

Since smoltification was induced in the completely castrated fish, but not in the fish which had a small piece of remaining testis, it follows that precocious gonadal maturation inhibits smoltification in the following spring. YamazakI et $a l^{8)}$ reported that methyltestosterone treatment induced desmoltification in the smolts of masu salmon. AIDA et al.* succeeded in inhibiting the natural smoltification with methylteststerone treatment using yearling masu salmon parr in early spring. In the partially castrated fish, plasma androgen level was lower $(1.14 \mathrm{ng} / \mathrm{m} l)$ than that of maturing fish in autumn. Although the testis of sham operated males became inactive and blood androgen content $(0.94 \mathrm{ng} / \mathrm{m} l)$ decreased after precocious maturation in autumn, these fish did not become smolt in spring. These results may indicate that androgen at the concentration of about $1 \mathrm{ng} / \mathrm{m} l$ is high enough to prevent the parr to smolt transformation or some unknown remaining effects of precocious maturation in autumn inhibits the transformation. In natural condition, lengthening daylength in spring probably induces smoltification, because artificial change in the photoperiod from short to long day induces smoltification in autumn in masu salmon. ${ }^{10,11)}$ Androgen may inhibits the activation of the hypothalamo-hypophyseal axis participating in the smoltification (probably the activation of the synthesis and secretion of thyroid stimulating hormone and/or growth hormone) 
which is probably triggered by the natural changes in environmental factors.

It is also clear that the growth is one of the important factors which induce smoltification, since only larger fish in the completely castrated group became smolt. The fish which had a small remaining piece of testis did not become smolt, but showed faster growth. Therefore, it is suggested that growth rate is not a sufficient condition for inducing smoltification but a necessary condition. Activation of pituitary somatotrophs during smoltification has been reported by CLARKe and NAGAHAMA. ${ }^{12)}$ Both telostean and mammalian growth hormone are considered to develop the sea water adaptability. ${ }^{18-15)}$

The fish which were classified as smolt in this experiment by the appearance were considered to be true smolts, since these fish showed high sea water adaptability. Changes in the body weight, plasma $\mathrm{Na}$ and $\mathrm{Mg}$ were adequate indicators of seawater adaptability.

Since plasma thyroxine gradually increases during the process of smoltification in spring and an additional surge is observed at the new moon before the peak of smoltification, ${ }^{8,18}$ ) the highest and lowest values which were found respectively in presmolt and sham operated parr in this experiment seem to be reasonable. But the significance of relatively high value found in the partially castrated parr is not known. More than half of the fish in this group had a small but active testis. High plasma throxine may have some relation to the commencement of spermatogenesis. Increase of plasma thyroxine was reported following seawater entrance in coho salmon, ${ }^{17}$ ) whereas in this experiment rapid decrease of plasma thyroxine was found after 24 hours in seawater. In coho salmon, the transient thyroxin peak at 24 hours is considered to be a reflection of pituitary stimulation of the thyroid, or an increase in thyroid efficiency due to the greater availability of environmental iodine in seawater. The artificial seawater which was used in this experiment contained enough amount of iodine. Therefore the decline in thyroxine may be induced by the decrease in TSH secretion or increase in turnover, but further investigation is considered to be necessary.

\section{Acknowledgements}

We thank Prof. Tetsuya Hirano and Miss Sanae HASEGAWA, Ocean Research Institute, The University of Tokyo, for carrying out the analyses of plasma ions and Mr. Yoshimi Fukuda and Umeji Axutsu, Nikko Branch of National Research Institute of Aquaculture, for their technical assistance. We also thank Prof. Isao Hanyu, Department of Fisheries, Faculty of Agriculture, The University of Tokyo for reading the manuscript. This study was partially aided by a Grantin-Aid for Scientific Research from the Ministry of Education, Science and Culture.

\section{References}

1) M. Osanai and M. Otsuka: Sci. Rep. Hokkaido Fish Hatchery, 22, 17-32 (1976).

2) M. Osanai and M. OtsuKa: Sci. Rep. Hokkaido Fish Hatchery, 24, 45-53 (1969).

3) S. SANo and Y. OZAKI: Sci. Rep. Hokkaido Salmon Hatchery, 23, 1-8 (1969).

4) T. Kuвo: Sci. Rep. Hokkaido Salmon Hatchery, 28, 9-26 (1974).

5) T. Kuво: Sci. Rep. Hokkaido Salmon Hatchery, 34, 1-95 (1980).

6) H. Uтон: Bull. Fac. Fish Hokkaido Univ., 26, 321-236 (1976).

7) Н. Uтон: Bull. Fac. Fish Hokkaido Univ., 28, 66-73 (1977).

8) W. W. DickHofF, L.C. FolmaR, and A. Gorbman: Gen. Comp. Endocrinol., 36, 229-232 (1978).

9) F. Yamazaki, T. Awakuwa, M. Atoda, and S. TANADA: Sci. Rep. Hokkaido Fish Hatchery, 29, 1-10 (1973).

10) S. Konno and S. NAKaE: Marine Ranching Program, Progress Rep. Masu Salmon, 1, 29-33 (1981).

11) S. Konno and S. NAKAE: Marine Ranching Program, Progress Rep. Masu Salmon, 2, 22-40 (1982)

12) W. C. Clarke and Y. Nagahama: Can. $J$. Zool., 55, 1620-1630 (1977).

13) M. P. Komourdian and R. L. SAUnders, and J.C. Fenwick: Can. J. Zool., 54, 531-535 (1976).

14) M. P. Komourdian, M. P. Burton, and D.R. IDLER: Gen. Comp. Endocrinol., 34, 158-162 (1978).

15) W. C. Clarke, S. W. Farmer, and K. M. HaRTWell: Gen. Comp. Endocrinol., 33, 174-178 (1977).

16) E. G. Grau, W. W. Dickhoff, R. S. Nishioka, H. A. Bern, and L. C. Folmar: Science, 211, 607-609 (1981).

17) L. C. Folmar, W. W. Dickroff: Comp. Biochem. Physiol., 63, 329-332 (1979). 


\section{Explanation of Plate}

Plate I-1. Typical appearance of smolt found in completely castrated masu salmon. Adipose fin was cut off to mark the castrated group.

2. Photograph of partially castrated parr. Adipose fin was also cut off.

3. Photograph of parr in sham operated group.

4. Remaining testis of partially castrated masu salmon, showing active spermatogenesis. $\times 250$

5. Inactive testis of sham operated parr. All the germ cells are at the stage of spermatogonia. 
Plate I.
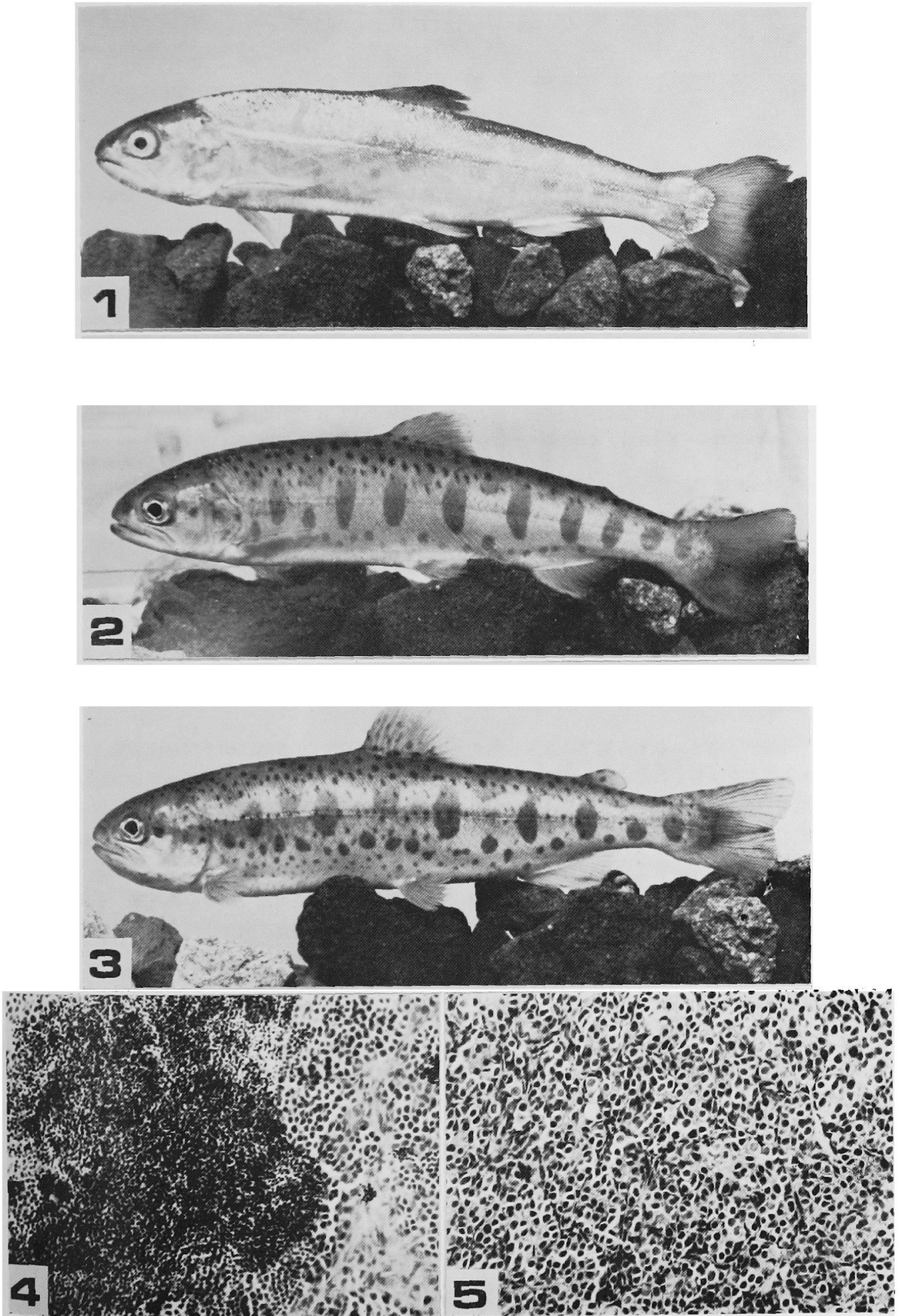